\section{Ordforklaringer}

Depresjon: Psykisk lidelse preget av vedvarende nedstemthet, tapt interesse for vanlige aktiviteter og redusert evne til å oppleve glede. Depresjon er den hyppigst forekommende psykiske lidelsen. Depresjon fører til betydelig tap av livskvalitet for dem som rammes og deres pårørende.

Hypertensjonsassosiert hypalgesi: Mindre smerte forårsaket av økt blodtrykk.

Se oversikt over doktoravhandlinger i seksjonen Oss imellom på side 964

\title{
Depresjon og søvn i barseltiden
}

\author{
Lite søvn kan være en forklaring på barselkvinners problemer med trett- \\ het og manglende krefter, men det kan også være tegn på depresjon.
}

Kvinners søvn forandres i barseltiden, men det har vært lite forskning på sammenhengen mellom endret søvnmønster og depresjon. Signe Karen Dørheim har undersøkt forekomst og risikofaktorer for depresjon etter fødselen hos kvinner i Norge og Nepal. I Norge ble også søvnmønsteret etter fødselen studert.

- I begge landene var depresjon i barseltiden relatert til dårlig søvn, et dårlig forhold til partneren, tidligere depresjon, depresjon under svangerskapet og påkjenninger det

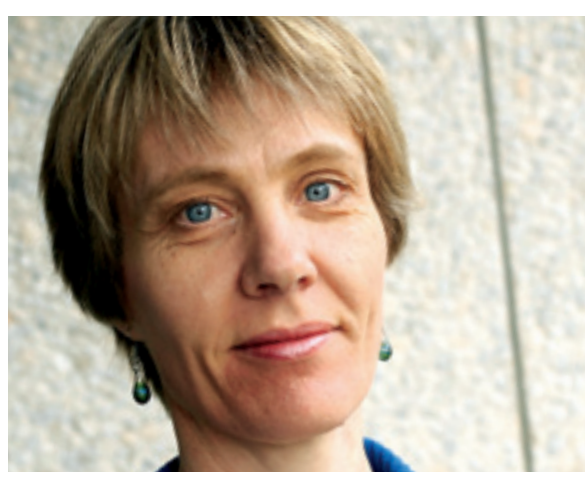

Signe Karen Dørheim. Foto Marte Monsen Strandskog, Stavanger universitetssjukehus siste året, som tap av nære pårørende eller sykdom, sier Dørheim.

Nær $60 \%$ av de norske barselkvinnene hadde søvnproblemer 7-11 uker etter fødselen. De fleste sov mindre enn anbefalt. Dårlig søvn var relatert til depresjon, men forekom også oftere hos førstegangsfødende, kvinner som kombinerte amming med flaskemelk, og kvinner som tidligere hadde søvnproblemer. Mødre som lot barnet sove på eget rom sov bedre.

- Søvnregistrering i 14 dager viste ikke søvnforskjeller mellom deprimerte og ikkedeprimerte kvinner, men de deprimerte hadde mindre overskudd om dagen. Manglende overskudd skyldes ikke alltid dårlig søvn, det kan også skyldes andre forhold som bekymrer og som stjeler energi. Det er viktig at helsepersonell er oppmerksomme på dette, sier hun.

Dørheim forsvarte avhandlingen Depression and sleep in the postnatal period. A study in Nepal and Norway for ph.d.-graden ved Universitetet i Bergen 17.3. 2009.

\section{Anne Forus}

anneforu@online.no

Tidsskriftet

\section{Blodtrykksmedisin mot migrene}

\author{
Blodtrykksmedisinen Atacand (candesartan) ser ut til å være \\ effektiv som forebyggende behandling mot migrene.
}

Atacand er en angiotensin II-reseptorblokker, og brukes til å behandle høyt blodtrykk. Erling Tronvik har i sin avhandling undersøkt om medikamentet også kan forebygge migrene. 60 pasienter inngikk i studien.

- Vi fant at Atacand egner seg godt til denne pasientgruppen, som i hovedsak er unge mennesker. Antall dager med hodepine ble redusert med $26 \% \mathrm{i}$ behandlingsperioden sammenliknet med placeboperioden. Antall timer med migrene ble redusert med $36 \%$. Medikamentet gir dessuten få bivirkninger, sier Tronvik.

En tidligere studie har vist effekt av ACE-hemmeren Zistril (lisinopril), og dessuten har betablokkere lenge vært vanlig i migrenebehandlingen. Men særlig sistnevnte kan ha en del bivirkninger, som f.eks. impotens og slapphet.
Tronvik har også undersøkt sammenhengen mellom høyt blodtrykk og migrene i befolkningen.

- Vi fant en invers sammenheng, hvor lavere blodtrykk var forbundet med mer hodepine - og omvendt. Spørsmålet er om dette kan være knyttet til fenomenet hypertensjonsassosiert hypalgesi, sier han, men understreker at pasienter ikke må slutte med blodtrykksmedisin for å unngå hodepine.

Tronvik disputerte for ph.d.-graden ved Norges teknisk-naturvitenskapelige universitet 12.3. 2009 med avhandlingen Migraine, blood pressure and the reninangiotensin system.

\section{Eline Feiring}

eline.feiring@legeforeningen.no

Tidsskriftet 